образованию для всех обучающихся с учетом разнообразия особых образовательных потребностей и индивидуальных возможностей».

Результаты проведенного нами анализа позволяют сделать некоторые частные выводы, представляющие интерес для нашего исследования. На современном этапе, на наш взгляд, выделяются основные вопросы в исследованиях инклюзивного образования в России и США. Во-первых, это определение критерий, согласно которым образовательное учреждение может считаться инклюзивным. Во-вторых - выделение основных понятий идентификации инклюзии в образовании. В-третьих, анализ изменений в развитии учащихся с ограниченными возможностями. И, наконец, сравнение данных эмпирических исследований, если в них принимают участие разные категории детей учащиеся с особыми потребностями и ограниченными возможностями.

$$
* * *
$$

1. Борисенко Е.Г. Основные вопросы формирования профессиональной компетенции студентов неязыкового вуза при обучении иностранным языкам в условиях дистанционного обучения. // Физическое воспитание и спортивная тренировка. - 2013. - №1(5). - Волгоград: ФГБОУ ВПО «ВГАФК», - С. 112-114.

2. Борисенко Е.Г., Кравченко О.А. Компетентностный подход к процессу обучения английскому языку в неязыковом вузе. // Современное профессиональное образование в сфере физической культуры и спорта: актуальные проблемы и пути совершенствования. - Волгоград, 2009. - С. 222-226.

3. Борисенко Е.Г., Кравченко О.А. Формирование лексики как основа успешной коммуникации на иностранном языке в неязыковых вузах. // Проблемы и перспективы внедрения информационных и коммуникационных технологий в физкультурное образование в контексте подготовки конкурентоспособного компетентного специалиста: материалы международной заочной электронной научно-методической конференции. - Волгоград, 2016. - С. 12-17.

4. Колчина Т.Ф. Особенности использования интернет-ресурсов при обучении грамматике иностранного языка студентов-спортсменов. // Физическое воспитание и спортивная тренировка. - 2016. - №1(15). Волгоград: ФГБОУ ВО «ВГАФК», - С. 95-99.

5. Колчина Т.Ф. Титры в англоязычных и русскоязычных кинотекстах 1930-х годов. // Инициативы XXI века. - 2012. - №3. - М.: Институт бизнеса, психологии и управления. - С. 164-166.

6. Колчина Т.Ф. Эволюция рамочных элементов кинотекста. // Экономические и гуманитарные исследования регионов. - 2014. - №4. - Р. н/Д.: ЗАО «Центр Универсальной Типографии». - С. 30-33.

7. Кравченко О.А. Мотивация спортивных волонтеров. // Физическое воспитание и спортивная тренировка. - 2015. - №3 (13). - Волгоград: ФГБОУ ВПО «ВГАФК», 2015. - С. 74-76.

8. Пономарева О.А. Политический имидж и его сущность // Коммуникативные технологии в образовании, бизнесе, политике и праве: материалы Международной научно-практической конференции 17-19 мая 2007г., Волгоград: Изд-во «ПринТерра». - Волгоград, 2007. - С. 94-99.

9. Пономарева О.А., Столбова Е.Г., Бабашев А.Э. Значение межкультурной коммуникации в обучении английскому языку студентов неязыковых вузов // Совершенствование лингвистической подготовки специалистов в области физической культуры и спорта: сб. науч. тр. преподавателей кафедры иностранных языков ВГАФК. - Волгоград: ФГОУ ВПО «ВГАФК», 2009. - С. 13-18.

10. Столбова Е.Г. Особенности обучения одаренных детей в начальной школе США: дис. ... канд. пед. наук: 13.00.01: Волгоград, 2005. - 174 с.

\title{
Иевлева А.М. \\ Приобщение учащихся начальных классов к чтению при помощи детской газеты «Кэскил»
}

Северо-Восточный федеральньй университет

(Россия, Якутск)

doi: $10.18411 / l j-30-11-2017-16$

idsp: 000001:lj-30-11-2017-16

\section{Аннотация}

В этой статье раскрыта важность приобщения детей к чтению с малых лет, а также польза чтения детских газет в начальных классах. В качестве примера была взята детская периодическая газета «Кэскил».

Ключевые слова: СМИ, газета, приобщение к чтению, внеклассные занятия. 
21 век является веком информационных технологий и нововведений. Уже с самого детства дети окружены различными гаджетами, благодаря которым им очень легко получить любую информацию, а также развлечься. Несомненно в этом есть свои положительные стороны, например: современные дети могут быстро находить информацию, быстрее развиваются, у них широкий кругозор. Но в то же время отношение детей к чтению сильно изменилось. Интерес стал стремительно падать. Многочисленные исследования в данной области говорят, что уже в дошкольном возрасте дети предпочитают книге просмотр телевизора, видео в интернете, а также различные компьютерные игры. У детей пропадает мотивация к чтению: зачем долго сидеть и вчитываться, если есть компьютерные игры и комиксы с картинками, при чтении которых не нужно сильно вдумываться.

Это общеизвестный факт, что человек, который не читает, не развивает и не совершенствует свои умственные и интеллектуальные способности, имеет короткую память и скудное воображение, а также может быть невнимательным и рассеянным. Из книги можно также усваивать и использовать опыт героев, анализировать их действия, что мотивирует читателя думать, сопоставлять и в итоге приходить к какому-то выводу.

Художественная литература издавна считается сильным и действенным средством нравственного, умственного и эстетического воспитания подрастающего поколения. Чтение художественной литературы расширяет словарный запас, благодаря чему речь становится красивее и правильнее.

Очень важно заранее воспитать любовь и интерес к книге. С.Я. Маршак считал основной задачей взрослых открыть в ребенке «талант читателя».

Вышеизложенное является наглядным примером того, что данная тема является актуальной на сегодняшний день.

Существуют различные методы работы по приобщению детей к чтению, например: заучивание наизусть, беседы по прочитанному, выразительное чтение, игрыдраматизации, элементы инсценирования, изображение прочитанного в изобразительной деятельности (лепке, рисовании, аппликации), театрализованная деятельность, показ иллюстраций, картинок, игрушек и т.д.

Одним из старых, но не менее действенных способов является использование газетных изданий для приобщения детей к чтению, в особенности учащихся начальных классов.

Однаков этот век информационных технологий образовательная и воспитательная роль СМИ и газет в частности не до конца осознана. Сложившиеся и общепринятые системы воспитания и обучения детей в семье и школе, а также содержание некоторых современных газет не позволяют оценить в полной мере роль газеты в решении актуальных задач приобщения детей к чтению.

Для того, чтобы заинтересовать ребенка и давать ему информацию, специально предназначенную для детей, необходимо правильно выбирать газету. В нашей Республике существует издательство под названием «Кэскил», которое является единственным издательством для детей. Газета выходит с 15 мая 1936 года под своим первым названием «Бэлэмбуол» (будь готов). С 1988 года издается на двух языках (якутском и русском). В 1990 газета «Бэлэмбуол» изменяет название на «Кэскил» и «Юность Севера».Из редакции детских газет «Кэскил», «Юность Севера» и журналов «Чуораанчык», «Колокольчик» переросла в детское издательство «Кэскил» имени Николая Егоровича Мординова-АммаАччыгыйа. На сегодняшний день газета «Кэскил» выходит 1 раз в неделю. Главной задачей издательства является воспитание и обучение. Для этого газета имеет множество рубрик, например «Айыына» для девочек, «Уолан» для мальчиков, «Сайдыс» про новые технологии и др. Самая интересная рубрика, по мнению издательства и читателей, - это рубрика с различными историями, рассказами и отрывками из художественной литературы. 
Для того, чтобы определить действенность использования газеты как средства приобщения детей к чтению, мы проводили один раз в неделю внеклассные занятия «Читай вместе с Кэскил» в МОБУ «Саха гимназия» среди учащихся 4 класса. Занятия проходили 45 минут. В качестве материала использовались отрывки из художественной литературы из рубрики газеты. В качестве разминки дети решали кроссворды, задачи, ребусы из газеты. Затем шла работа непосредственно над текстом. Самое главное подбирать тексты, учитывая школьную программу. В чем же отличия от простого отрывка из учебника и детской газеты? Во-первых, газета яркая и цветная и к рассказам также бывают иллюстрации, картинки, которые нарисовали сами дети. Во-вторых, информация подается на простом языке, который могут понять дети, потому что обычную черно-белую газету порой и взрослым не хочется читать. В-третьих, в газете присутствуют другие образовательные рубрики, которые можно использовать на уроках и внеклассных занятиях, а также немаловажно то, что кроссворды, задачки и тексты из газеты бывают связаны, что является дополнительной мотивацией для ребенка прочитать внимательно текст.

Внеклассные занятия проводились два месяца, было проведено 8 занятий. По итогам работы мы провели литературный вечер, в котором учащиеся и их родители принимали активное участие. А также каждый ребенок выполнил творческое задание: кто-то написал историю или рассказ, кто-то сочинил стихотворение или нарисовал рисунок. Все работы будут опубликованы в газете «Кэскил».

Для того, чтобы ребенок читал и вне школы, важно, чтобы родители принимали активное участие в деятельности ребенка. Интересно отметить, что родители, которые сделали подписку на газету «Кэскил» - это родители, которые читают данную газету вместе с ребенком. Поэтому роль родителей в приобщении детей к чтению немаловажна.

В итоге мы можем прийти к выводу, что приобщение детей к чтению является актуальным вопросом на сегодняшний день и существуют различные методы для популяризации чтения, одной из которых является использование детской газеты на уроках или внеклассных занятиях.

$$
* * *
$$

1. Дунаева Н. О значении художественной литературы в формировании личности ребенка. // Дошкольное воспитание. - 2007. №6. - С 35-40.

2. Колобова О. А. Эффективные формы и методы работы по развитию интереса к художественной литературе у детей среднего дошкольного возраста [Текст] // Актуальные задачи педагогики: материалы VI Междунар. науч. конф. (г. Чита, январь 2015 г.). - Чита: Издательство Молодой ученый, 2015. — C. 37-45. URL: https://moluch.ru/conf/ped/archive/146/6129/

3. Нисина Наталья. Приобщение детей дошкольного возраста к чтению художественной литературы,[электронный источник]http://www.maam.ru/detskijsad/priobschenie-detei-doshkolnogovozrasta-k-chteniyu-hudozhestvenoi-literatury.html

\section{Курманаева Г.М., Хаустов С.Л. \\ Особенности активизации учебно-воспитательного процесса учащихся на уроках технологии}

Стерлитамакский филиал Башкирского Государственного Университета (Россия, Стерлитамак)

doi: 10.18411/lj-30-11-2017-17

idsp: 000001:lj-30-11-2017-17

В наше время человечество переживает четвёртую технологическую революцию. Из-за широкого применения информационных и телекоммуникационных технологий, быстрой сменой технологий главным в современном производстве становится работа с новой информацией и творческое решение постоянно возникающих задач. 